\section{SIMULASI PERUBAHAN PENGGUNAAN LAHAN DENGAN KONSEP CELLULER AUTOMATA DI KOTA MATARAM}

\author{
Muhammad Rusdin Rangga Putra ${ }^{1)}$, Iwan Rudiarto ${ }^{2)}$ \\ ${ }^{1)}$ Badan Pertanahan Nasional Provinsi Nusa Tenggara Barat \\ ${ }^{2)}$ DepartemenPerencanaan Wilayah dan Kota, Fakultas Teknik, \\ Universitas Diponegoro
}

\author{
Jurnal Pengembangan Kota (2018) \\ Volume 6 No. 2 (174-185) \\ Tersedia online di: \\ http://ejournal2.undip.ac.id/index.php/jpk \\ DOI: 10.14710/jpk.6.2.174-185
}

\begin{abstract}
Abstrak. Dinamika perubahan penggunaan lahan dapat dipahami secara spasial dengan memanfaatkan data penginderaan jauh dan sistem informasi geografis. Penelitian ini bertujuan membangun model perubahan penggunaan lahan di Kota Mataram untuk memprediksi penggunaan lahan di Kota Mataram pada tahun 2031. Model yang dibangun adalah hasil analisis spasial dari pola perubahan penggunaan lahan dari kurun waktu tahun 2008 sampai tahun 2017 dengan menggunakan konsep Cellular Automata. Penentuan bobot masing-masing faktor perubahan penggunaan lahan dilakukan dengan menggunakan metode AHP. Hasil pemodelan divalidasi dengan menggunakan peta penggunaan lahan tahun 2017 menujukkan tingkat akurasi sebesar 84,18\% yang mengindikasikan bahwa model dapat diterima. Model juga dapat memprediksi, bahwa akan terjadi peningkatan secara signifikan luasan penggunaan lahan industri dan pergudangan, perdagangan dan jasa, dan permukiman di Kota Mataram berturut-turut sebesar 9,861 Ha, 355,354 Ha, dan 482,697 Ha sampai dengan tahun 2031. Pemanfaatan simulasi perubahan penggunaan lahan dengan konsep Cellular Automata ini dapat diterapkan sebagai alat evaluasi kebijakan.
\end{abstract}

Kata kunci: celluler automata; Kota Mataram; perubahan penggunaan lahan

[Title: Simulation of Land Use Changes Using Celluler Automata in Mataram City]. The dynamics of land use changes can be understood spatially by utilizing remote sensing data and geographic information systems. This study aims to establish a model of land use change in Mataram City to predict land use in the Mataram City in 2031. The model was built based on spatial analysis of land use change patterns from the period 2008 to 2017 using the concept of Cellular Automata. Determination of weighted value of each change factor in land use is carried out using AHP method. The modeling results were validated using the 2017 land use map showing an accuracy rate of $84.18 \%$ which indicates that the model is acceptable. The model can also predict that there will be a significant increase in the area of industrial land use and warehousing, trade and services, and settlements in Mataram City in the amount of 9.861 Ha, $355.354 \mathrm{Ha}$, and 482.697 Ha until 2031. Utilization of land use change simulations with the Cellular Automata concept can be applied as a policy evaluation tool.

Keywords: celluler automata, land use change, Mataram City

Cara mengutip: Putra, M. R. R., \& Rudiarto, I. (2018). Simulasi Perubahan Penggunaan Lahan dengan Konsep Celluler Automata di Kota Mataram. Jurnal Pengembangan Kota. Vol 6 (2): 174-185. DOI: 10.14710/jpk.6.2.174-185

\section{PENDAHULUAN}

Pertumbuhan perkotaan merupakan proses sosial dan populasi multidimensional dimana kota dianggap menjadi pusat perekonomian yang merupakan komponen utama dalam pemenuhan kebutuhan manusia (Dadras, Shafri, Ahmad, Pradhan, \& Safarpour, 2015). Perkembangan perkotaan di Indonesia cukup pesat dalam beberapa tahun terakhir. Hal ini sesuai dengan data World Bank pada tahun 2010 dimana diperkirakan
$68 \%$ dari total penduduk di Indonesia tinggal diperkotaan pada tahun 2025. Menurut United Nations (2018), pada tahun 2050 dua pertiga

\section{ISSN 2337-7062 @ 2018}

This is an open access article under the CC-BY-NC-ND license (http://creativecommons.org/licenses/by-nc-sa/4.0/). - lihat halaman depan (C) 2018

*Email rusdin.rangga00@gmail.com

Diterima 20 November 2018, disetujui 20 Desember 2018 
populasi Indonesia akan tinggal di wilayah perkotaan. Kebutuhan sumber daya lahan untuk pembangunan perkotaan dan pertumbuhan penduduk menyebabkan fenomena perubahan penggunaan lahan dengan pola spasial tertentu sehingga pengelolaan pertumbuhan perkotaan menjadi fenomena yang sangat kompleks dan tantangan tersendiri dalam penyelesaiannya (Cohen, 2006). Pemanfaatan lahan pada suatu perkotaan tertentu tanpa dilakukannya perencanaan yang baik akan menciptakan ketidakseimbangan dalam aktivitas pembangunan kota (Fuglsang, Münier, \& Hansen, 2013). Aryany dan Pradoto (2014) menjelasakan bahwa adanya keterbatasan lahan, persaingan penggunaan lahan dan pertumbuhan penduduk yang pesat menyebabkan laju perkembangan kota mengalami proses pergeseran penggunaan lahan.

Perubahan penggunaan lahan dipengaruhi oleh pembangunan ekonomi serta perubahan lingkungan dan sosial yaitu dengan peningkatan industrialisasi, urbanisasi, pertumbuhan jumlah penduduk dan reformasi ekonomi (Gu, Guo, Fan, \& Chan, 2016). Perubahan penggunaan lahan di suatu daerah cenderung merupakan cerminan dari perkembangan ekonomi dan pertumbuhan penduduk. Menurut Kaiser, Godschalk, dan Chapin (1995), perubahan guna lahan adalah interaksi yang disebabkan oleh tiga komponen pembentuk guna lahan, yaitu sistem pembangunan, sistem aktivitas dan sistem lingkungan hidup. Perubahan penggunaan lahan dapat terjadi karena adanya faktor pendorong sebagai unsur yang berpengaruh terhadap perubahan suatu jenis penggunaan lahan tertentu. Faktor pendorong terjadinya konversi lahan dapat dikelompokkan menjadi lima hal Dendoncker, Rounsevell, dan Bogaert (2007), yaitu faktor biofisik, faktor sosial, faktor ekonomi, kebijakan tata ruang, serta interaksi keruangan dan karakteristik penggunaan lahan sekitarnya. Hubungan antara faktor pendorong tersebut dapat memicu perubahan penggunaan lahan baik secara langsung maupun tidak langsung. Faktor pendorong perubahan penggunaan lahan tersebut kemudian dapat diturunkan dalam beberapa variabel yang mendorong terjadinya perubahan penggunaan lahan (Sadewo \& Buchori, 2018).

Pemahaman perubahan pengunaan lahan secara spasial dapat membantu dalam memahami dinamika perkembangan perkotaan. Selain itu, Informasi terkait perubahan tutupan lahan yang akurat dan mutakhir dapat digunakan untuk memahami dan menilai kerusakan lingkungan yang disebabkan alih fungsi lahan (Deep \& Saklani, 2014). Secara teknis, dinamika perubahan penggunaan lahan dapat dipahami secara spasial dengan memanfaatkan data penginderaan jauh dan sistem informasi geografis. Pemanfaatan data penginderaan jauh dan sistem informasi geografis tersebut dapat dibuat untuk membangun model penggunaan lahan, yang salah satunya dengan mengaplikasikan konsep cellular automata (Deep \& Saklani, 2014; Fuglsang, dkk., 2013; Gharbia, Alfatah, Gill, Johnston, \& Pilla, 2016; Mosammam, Nia, Khani, Teymouri, \& Kazemi, 2017; Pratomoatmojo, 2018). Selanjutnya, pola perubahan penggunaan lahan yang terjadi dapat dibangun modelnya, yang merupakaan tiruan wujud atau representasi kondisi sesungguhnya dari pola perubahan lahan tersebut dalam bentuk yang sederhana untuk memahami dan menggambarkan secara utuh bagaimana fenomena perubahan penggunaan lahan tersebut terjadi.

Beberapa penelitian terkait pemodelan penggunaan lahan dengan menggunakan cellular automata telah dilakukan terutama dengan kasus pada kawasan cepat tumbuh. Misalnya, Gharbia, dkk. (2016) berhasil mengkuantifikasi perluasan kota masa depan di daerah Basin Sungai Shannon dan menyelidiki dinamika spatio-temporal dari faktor pertumbuhan perkotaan dengan akurasi model sebesar $89,01 \%$ untuk tahun 2006 dan untuk tahun 2012 akurasi sebesar 87,09\%. Selain itu, Sadewo dan Buchori (2018) juga melakukan penelitian perubahan penggunaan lahan dengan memprediksi perubahan penggunaan lahan akibat pengaruh pembangunan kawasan industri berbasis celluler automata dengan hasil akurasi model sebesar 95,68\%. Namun penelitian model perubahan penggunaan lahan di Kota Mataram dengan menggunakan pendekatan celluler automata belum pernah dilakukan. Berdasarkan RPJMD Kota Mataram tahun 2016, perubahan penggunaan lahan terjadi begitu cepat di Kota Mataram, penggunaan lahan mengalami alih fungsi yang cukup signifikan dari lahan pertanian, kawasan hijau dan daerah tangkapan air menjadi permukiman, perdagangan dan perkantoran. Alih fungsi lahan tersebut membawa dampak terhadap 
struktur tata ruang kota serta daya dukung lahan dan lingkungan hidup lainnya, sehingga penelitian ini penting untuk dilakukan.

Berdasarkan hal tersebut, penelitian ini bertujuan untuk membangun model perubahan penggunaan lahan di Kota Mataram sebagai masukan dalam mengkaji Rencana Tata Ruang dan Wilayah Kota, penyusunan RDTR serta perencanaan dan pengendalian pembangunan. Model perubahan penggunaan lahan dapat dipahami secara spasial dengan memanfaatkan data penginderaan jauh dan sistem informasi geografis. Pemodelan prediksi perubahan lahan dilakukan dengan mempertimbangkan kebutuhan lahan dan kesesuaian lahan serta faktor pendorong maupun faktor penghambat terjadinya perubahan lahan.

\section{METODE PENELITIAN}

Lokasi penelitian ini terletak di Kota Mataram. Secara administrasi luas wilayah Kota Mataram adalah $60,21 \mathrm{~km}^{2}$ yang terbagi dalam 6 kecamatan yaitu Kecamatan Ampenan, Kecamatan Sekarbela, Kecamatan Mataram, Kecamatan Selaparang, Kecamatan Cakranegara dan Kecamatan Sendubaya (Gambar 1). Enam kecamatan ini terbagi dalam 50 kelurahan. Secara rata-rata, luas setiap kecamatan berkisar antara 15 hingga 18 persen dari luas total Kota Mataram. Adapun batas sebelah utara, timur dan selatan berbatasan dengan Kabupaten Lombok Barat dan sebelah barat berbatasan dengan Selat Lombok. Kedudukannya sebagai ibu kota provinsi membuat Kota Mataram mengalami pertumbuhan penduduk yang pesat sehingga perubahan penggunaan lahan pun semakin tinggi.

Data dan informasi tentang penggunaan lahan dalam penelitian ini dikumpulkan melalui survei primer dan sekunder. Survei data primer dengan cara survei dan observasi lapangan terkait penggunaan lahan. Sedangkan survei data sekunder diperoleh dengan mengunduh citra dari Google Earth tahun 2008 dan 2017 untuk klasifikasi penggunaan lahan tahun 2008 dan tahun 2017. Adapun peta pola ruang RTRW Kota Mataram tahun 2011-2031 dan peta sarana dan prasarana diperoleh dari Dinas Badan Perencanaan dan Pembangunan Daerah dan Dinas Pekerjaan Umum Perumahan Rakyat Kota Mataram. Alasan pemakaian citra yang bersumber dari Google Earth adalah sebagai berikut: (1) keterbatasan sumber dana untuk memperoleh CSRT paling mutakhir; (2) keterbatasan waktu penelitian yang tidak memunginkan untuk memperoleh data foto udara dengan memakai UAV; (3) citra dari Google Earth mampu menyajikan data spasio temporal yang dirasa cukup memadai; dan (4) penelitian sejenis yang mensimulasikan perubahan penggunaan lahan juga mempergunakan sumber yang sama seperti penelitian.

Metode analisis yang digunakan dalam penelitian ini adalah metode berbasis spasial temporal dengan pendekatan kuantitatif. Adapun ukuran piksel yang digunakan dalam proses simulasi yaitu $10 \times 10 \mathrm{~m}$ dengan tujuan untuk mengoptimalkan kualitas data sesuai luas area penelitian. Penelitian ini dilakukan di Kota Mataram dengan faktor pendorong perubahan penggunaan lahan yang digunakan antara lain jarak ke industri dan pergudangan eksisting, jarak ke perdagangan dan jasa eksisting, permukiman eksisting, jarak ke sarana perkantoran, jarak ke sarana pendidikan, jarak ke sarana kesehatan, jarak ke jalan utama dan jarak ke jalan lokal (Sadewo \& Buchori, 2018). Penghitungan nilai pengaruh (bobot) variabel menggunakan analisis sederhana dengan metode AHP (Analytical Hierarchy Process). Sadewo dan Buchori (2018) menerapkan analisis sederhana metode AHP untuk memperoleh nilai pengaruh tiap variabel pendorong terhadap perkembangan perubahan penggunaan lahan dengan memprediksi perubahan penggunaan lahan akibat pengaruh pembangunan kawasan industri di Kota Kendal. Tahapan analisis yang dilakukan dalam penelitian sebagai berikut.

\section{A. Analisis Perubahan Penggunaan Lahan}

Analisis ini bertujuan untuk mengetahui pola perubahan penggunaan lahan yang terjadi selama kurun waktu 2008 - 2017 baik dari segi distribusi masing-masing penggunaan lahan maupun luasan penggunaan lahan. Teknik Analisis dilakukan dengan cara interpretasi citra dari Google Earth tahun 2008 dan 2017 yang dikombinasikan dengan ground check untuk memastikan kondisi di lapangan sesuai dengan visualisasi citra. Tujuan dilakukan interpretasi adalah untuk mengklasifikasi penggunaan lahan dalam beberapa kelas penggunaan sesuai dengan klasifikasi yang diajukan oleh Kaiser, dkk. (1995). 


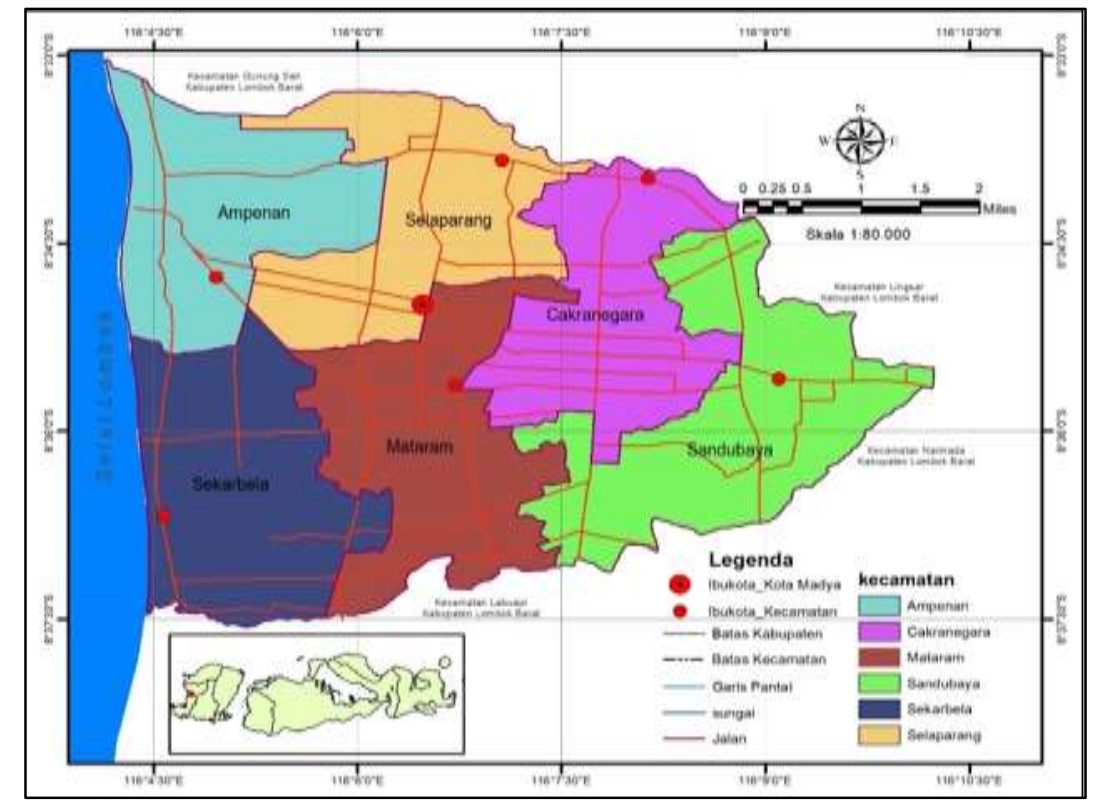

Gambar 1. Wilayah Studi Penelitian

Hasil analisis penggunaan lahan tahun 2008 dan tahun 2017 dapat dihitung pola pertumbuhan penggunaan lahan pertahun untuk melakukan prediksi penggunaan lahan tahun 2031.

\section{B. Membangun model perubahan penggunaan lahan.}

Konsep cellular automata telah dikembangkan sejak tahun 1940 dalam bidang komputer oleh Von Neumann dan Ulam. Cellular automata merupakan sebuah mesin otomatis yang memproses informasi dengan program yang ada di dalamnya yang terbentuk dari unsur-unsur antara lain Cell, State Set, Neighbourhood, Transition rules dan Time-step. Longley dan Batty (2003) mampu mensimulasikan sistem yang kompleks menjadi sederhana (Liu \& He, 2009). Walaupun sederhana, CA mampu untuk melakukan perhitungan universal (Wolfram, 1982) serta mampu memodelkan proses spasial temporal yang kompleks (Barredo, Kasanko, McCormick, \& Lavalle, 2003). Dengan konsep CA keadaan setiap cell pada array akan bergantung pada keadaan sel awal dalam lingkungan berdasarkan aturan transisi (White, Engelen, \& Uljee, 1997). Susunan sel-sel tersebut dapat membentuk grid segi empat sederhana maupun susunan lain seperti sarang lebah yang terdiri dari bagian-bagian berbentuk segi enam (heksagonal).

Pada tahapan membangun peta simulasi perubahan penggunaan lahan untuk penelitian ini yang dilakukan diantaranya adalah identifikasi penggunaan lahan eksisting dan laju pertumbuhan penggunaan lahan kemudian membuat peta potensi perkembangan perubahan penggunaan lahan serta menentukan neighbourhood filter dan constraint variable. Aturan transisi akan dapat menentukan bagaimana suatu simulasi perubahan penggunaan lahan berjalan. Menurut Pratomoatmojo (2018), landusesim merupakan aplikasi berbasis raster yang menggunakan algoritma celluler automata untuk melakukan simulasi spasial dan memungkinkan pengguna mengontrol semua faktor dalam proses simulasi spasial seperti target pertumbuhan, penentuan faktor pendorong serta membuat beberapa skenario perencanaan baik berbasis target maupun trend. Gambar 2 menunjukkan algoritma celluler automata pada software landusesim.

Selanjutnya, uji akurasi model diperlukan untuk mengukur tingkat akurasi model prediksi sehingga dapat diketahui tingkat validitasnya. Pada studi ini nilai akurasi (dalam persen) dihitung dari luas sel pengunaan lahan hasil simulasi tahun 2017 dengan luas eksisting tahun 2017. Peta penggunaan lahan hasil simulasi tahun 2017 dengan peta penggunaan lahan eksisting tahun 2017 dilakukan operasi overlay untuk mengetahui nilai akurasi dari model yang dibangun. 


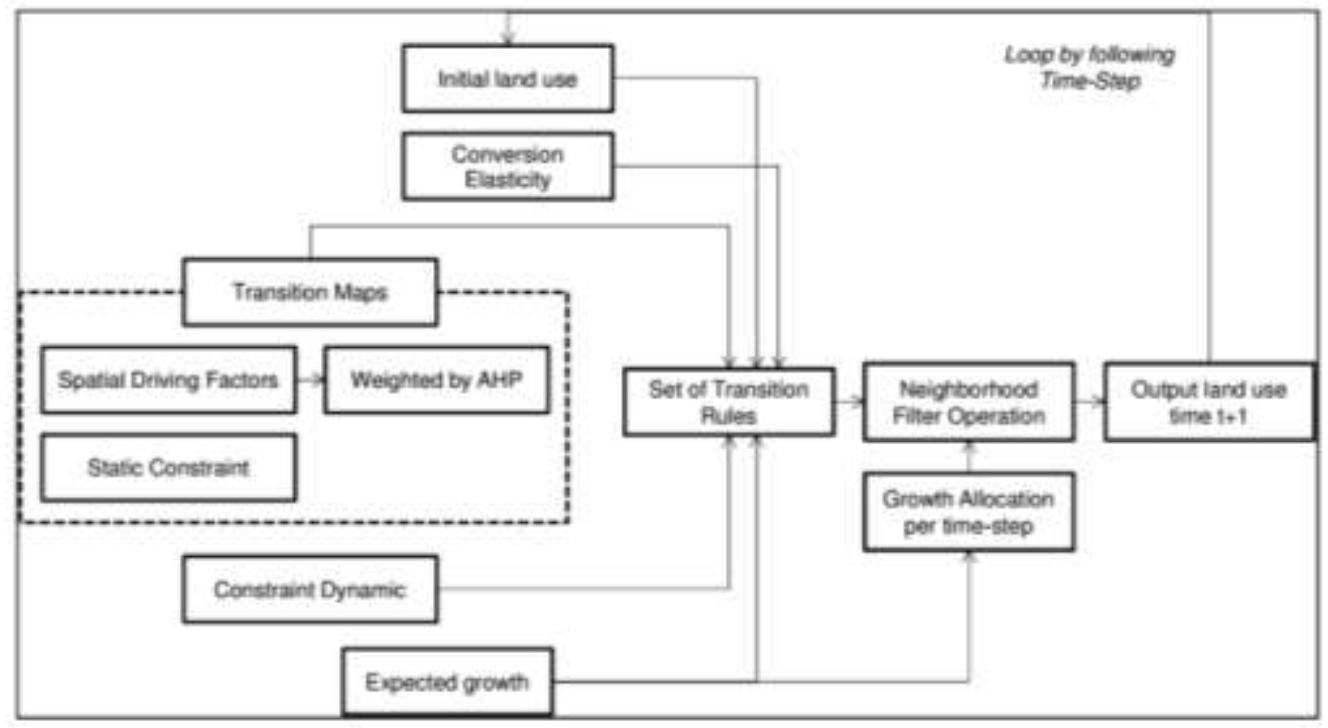

Gambar 2. Algoritma Celluler Automata Pada Landusesim (Pratomoatmojo, 2018)

\section{HASIL DAN PEMBAHASAN}

\section{Perubahan Penggunaan Lahan}

Kota Mataram mengalami perubahan penggunaan lahan yang cepat selama periode 2008-2017. Hasil identifikasi dan klasifikasi citra diperoleh kelas penggunaan lahan yang terdiri dari industri dan pergudangan, perdagangan dan jasa, sarana transportasi, permukiman, pertanian, taman kota dan sungai. Klasifikasi penggunaan lahan ini sesuai dengan klasifikasi yang diajukan oleh Kaiser, dkk. (1995). Klasifikasi citra tersebut menggunakan metode digitizing on screen, dengan software ArcGis 10.3 dalam format vektor (Gambar 3). Berdasarkan klasifikasi citra mengungkapkan bahwa dari tahun 2008 hingga 2017 terjadi perubahan penggunaan lahan permukiman menjadi industri dan pergudangan serta perdagangan dan jasa (lihat Tabel 1). Penggunaan lahan permukiman mengalami perubahan menjadi industri dan pergudangan seluas 3,121 hektar dan menjadi perdagangan dan jasa seluas 84,652 hektar. Pada tahun 2017 penggunaan lahan pertanian mengalami perubahan menjadi industri dan pergudangan seluas 13,961 hektar.

Selain itu juga terjadi perubahan penggunaan lahan menjadi perdagangan dan jasa seluas 146,269 hektar serta menjadi permukiman seluas 602,771 hektar. Penggunaan lahan lainnya seperti industri dan pergudangan, perdagangan dan terbesar juga terjadi di Kecamatan Sandubaya. Adanya Terminal Mandalika, Pasar Induk Bertais serta pelebaran jalan menuju Pelabuhan Lembar menyebabkan semakin mudahnya distribusi barang dan jasa sehingga masyarakat semakin banyak yang menjadikan permukiman menjadi industri dan pergudangan serta perdagangan dan jasa karena dianggap lebih menguntungkan. Kecamatan Sandubaya juga mengalami perubahan penggunaan lahan dari pertanian menjadi industri dan pergudangan dengan luasan yang paling besar dibandingkan dengan kecamatan lainnya.

Perubahan penggunaan lahan pertanian menjadi perdagangan dan jasa banyak terjadi di Kecamatan Sekarbela. Hal ini dikarenakan pada wilayah ini telah dibangun jalan lingkar selatan Kota Mataram untuk memudahkan akses menuju Pelabuhan Lembar dan Bandara Internasional Lombok sehingga semakin menarik masyarakat untuk menjadikan pertanian menjadi perdagangan dan jasa. Hal ini memperkuat penelitian oleh Gharbia, dkk. (2016) yang menyebutkan bahwa transportasi memiliki peran penting dalam perkembangan kota karena sebuah sistem transportasi yang baik meningkatkan aksesibilitas dan menurunkan biaya pembangunan. Tingkat aksesibilitas yang semakin baik juga semakin mendorong masyarakat untuk bermukim di wilayah tersebut sehingga berdampak pada semakin berkurangnya penggunaan lahan untuk pertanian dan semakin meningkatnya lahan permukiman. 


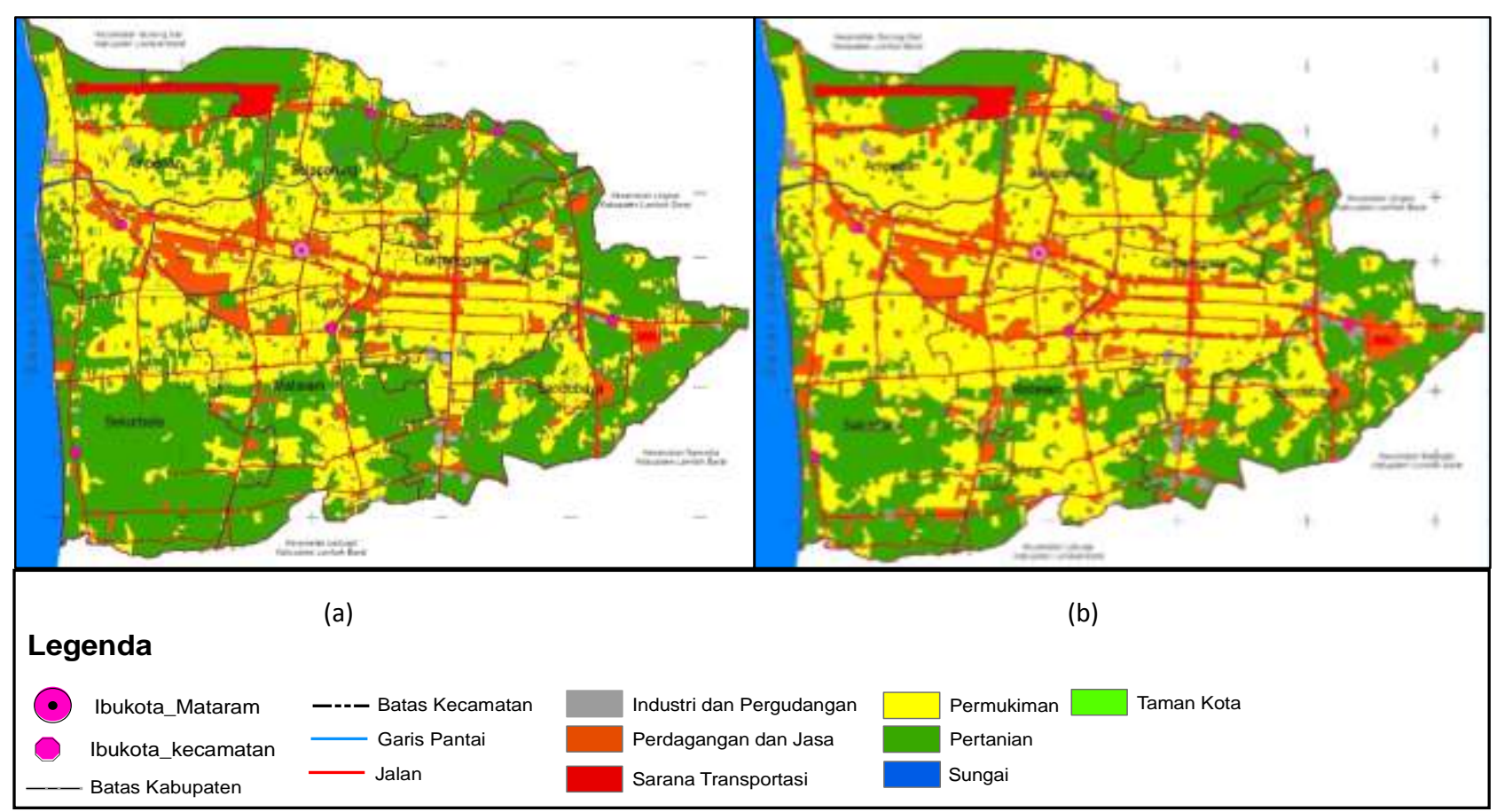

Gambar 3. Perbandingan Penggunaan Lahan (a) Tahun 2008 dan (b) Tahun 2017

Tabel 1. Matrik Perubahan Penggunaan Lahan di Kota Mataram Tahun 2008-2017

\begin{tabular}{|c|c|c|c|c|c|c|c|c|c|}
\hline \multirow{2}{*}{\multicolumn{2}{|c|}{$\begin{array}{c}\text { Perubahan } \\
\text { Penggunaan Lahan }\end{array}$}} & \multicolumn{8}{|c|}{ Luas Penggunaan Lahan (Hektar) Tahun 2017} \\
\hline & & LU_ 1 & LU_2 & LU_3 & LU_4 & LU_5 & LU_6 & LU_7 & Total \\
\hline \multirow{8}{*}{ 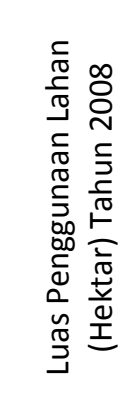 } & LU_1 & 59,47 & 0 & 0 & 0 & 0 & 0 & 0 & 59,47 \\
\hline & LU_2 & 0 & 523,874 & 0 & 0 & 0 & 0 & 0 & 523,874 \\
\hline & LU_3 & 0 & 0 & 72,028 & 0 & 0 & 0 & 0 & 72,028 \\
\hline & LU_4 & 3,121 & 84,652 & 0 & $2.459,38$ & 0 & 0 & 0 & $2.547,15$ \\
\hline & LU_5 & 13,961 & 146,269 & 0 & 602,771 & $2.020,97$ & 0 & 0 & $2.783,97$ \\
\hline & LU_6 & 0 & 0 & 0 & 0 & 0 & 17,93 & 0 & 17,93 \\
\hline & LU_7 & 0 & 0 & 0 & 0 & 0 & 0 & 16,625 & 16,625 \\
\hline & Total & 76,553 & 754,795 & 72,028 & $3.062,15$ & $2.020,97$ & 17,93 & 16,625 & $6.021,05$ \\
\hline
\end{tabular}

Keterangan LU_1 : Industri dan Pergudangan, LU_2 : Perdagangan dan Jasa, LU_3 : Transportasi, LU_4 : Permukiman, LU_5 : Pertanian, LU_6: Sungai dan LU_7 : Taman Kota.

\section{Laju Pertumbuhan Penggunaan Lahan}

Simulasi perubahan penggunaan lahan tahun 2017 berdasarkan data pertumbuhan beberapa jenis penggunaan lahan yang mengalami perkembangan berdasarkan analisis laju perubahan penggunaan lahan di tahun 2008 sampai tahun 2017. . Laju perubahan penggunaan lahan yang diperoleh masih berupa data vektor penggunaan lahan yang dirubah menjadi format raster sebagai dasar dalam proses simulasi. Untuk melakukan konversi data vektor menjadi data raster penelitian ini menggunakan software ArcGIS 10.3. Data raster inilah yang akan digunakan dalam proses simulasi penggunaan lahan masa depan. Ukuran sel yang digunakan dalam penelitian ini yaitu $10 \times 10 \mathrm{~m}\left(100 \mathrm{~m}^{2}\right)$ untuk setiap selnya. Dalam proses perhitungan luas diwakili dengan jumlah sel untuk setiap jenis penggunaan lahan, dimana setiap sel mewakili luas $100 \mathrm{~m}^{2}$. Pertumbuhan lahan untuk industri dan pergudangan sebesar 1.713 sel, perdagangan dan jasa sebesar 23.163 sel, permukiman sebesar 51.435. Kemudian laju perubahan penggunaan lahan di tahun 2017 sampai tahun 2031 digunakan sebagai dasar untuk melakukan simulasi perubahan penggunaan lahan tahun 2031 dimana 
pertumbuhan lahan untuk industri dan pergudangan sebesar 2.660 sel, perdagangan dan jasa sebesar 36.036 sel, permukiman sebesar 81.340 sel.

\section{Peta Potensi Perkembangan Perubahan Penggunaan Lahan}

Setelah dilakukan identifikasi penggunaan lahan eksisting dan laju pertumbuhan penggunaan lahan, tahapan selanjutnya membuat peta potensi perkembangan perubahan penggunaan lahan serta menentukan neighbourhood filter dan constraint variable. Pada penelitian ini yang digunakan sebagai peta transisi yaitu penggunaan lahan yang mengalami pertumbuhan antara lain permukiman, perdagangan dan jasa serta industri dan pergudangan. Peta transisi yang dibuat sangat tergantung dari persebaran faktor pendorong perubahan penggunaan lahan yang kemudian dihitung jangkauan dan bobot dari faktor pendorong tersebut.

Penentuan faktor pendorong dilakukan berdasarkan pada penelitian-penelitian sebelumnya. Pada penelitian Gharbia, dkk. (2016), faktor-faktor pendorong perubahan lahan terbangun yang dianalisis adalah jarak ke jalan utama, jarak ke jalan lokal, jarak ke pusat kota, jarak terhadap area perkotaan eksisting, jarak terhadap area populasi padat, jarak terhadap area populasi sedang serta jarak terhadap area populasi jarang. Kemudian dalam penelitian Sadewo dan Buchori (2018), faktor-faktor pendorong perubahan lahan yang dianalisis adalah jarak ke kemiringan lereng, jarak terhadap rawan bencana, jarak ke sungai sebagai variabel biofisik, jarak ke pusat kota, Jarak ke pusat pemerintahan, jarak ke pusat perdagangan, jarak ke kawasan industri, jarak ke pelabuhan sebagai variabel soisal ekonomi jarak ke fasilitas peribadatan, jarak ke fasilitas pendidikan, jarak ke fasilitas kesehatan sebagai variabel sarana prasarana, jalan arteri, jalan kolektor, jalan lokal, jalan kereta api, interchange jalan tol sebagai variabel aksesibilitas, jarak ke permukiman, perdagangan dan jasa, industri, perkantoran sebagai variabel ketetanggaan serta kawasan lindung sebagai variabel kebijakan tata ruang. Sesuai dengan karakteristik Kota Mataram, penelitian ini menggunakan faktor-faktor pendorong perubahan lahan antara lain, jarak ke industri dan pergudangan, jarak ke perdagangan dan jasa, jarak ke permukiman, jarak ke sarana perkantoran, jarak ke sarana pendidikan, jarak ke sarana kesehatan, jarak ke jalan utama dan jarak ke jalan lokal.

Pada pembobotan untuk perkembangan lahan industri dan pergudangan, setelah dilakukan proses pengolahan menggunakan software expert choice, diperoleh besaran bobot untuk masing-masing variabel sebagai berikut; industri dan pergudangan sebesar $39,2 \%$, jarak ke jalan utama sebesar $25,5 \%$, jarak ke jalan lokal sebesar $8,9 \%$, perdagangan dan jasa sebesar $7,5 \%$, jarak ke kantor pemerintahan sebesar $6 \%$, jarak ke sarana pendidikan sebesar $5,1 \%$, jarak ke sarana kesehatan sebesar $4,3 \%$ dan permukiman sebesar $3,6 \%$. Untuk pembobotan perkembangan lahan perdagangan dan jasa diperoleh besaran bobot untuk masing - masing variabel sebagai berikut; perdagangan dan jasa sebesar $39,7 \%$, jarak ke jalan utama sebesar $29,8 \%$, jarak ke jalan lokal sebesar 7,6\%, permukiman sebesar 6,4\%, jarak ke kantor pemerintahan sebesar 5,4\%, jarak ke sarana pendidikan sebesar $4,6 \%$, jarak ke sarana kesehatan sebesar 3,9\% serta industri dan pergudangan sebesar $2,5 \%$.

Sedangkan untuk pembobotan perkembangan lahan permukiman diperoleh besaran bobot untuk masing-masing variabel sebagai berikut; permukiman sebesar $37,8 \%$, jarak ke jalan lokal sebesar $25,9 \%$, jarak ke sarana pendidikan sebesar $10,4 \%$, jarak ke sarana kesehatan sebesar $8,3 \%$ jarak ke kantor pemerintahan sebesar $6,3 \%$, jarak ke jalan utama sebesar $5 \%$, perdagangan dan jasa sebesar $3,9 \%$, serta industri dan pergudangan sebesar $2,3 \%$.

Pada peta transisi potensi perkembangan penggunaan lahan untuk industri dan pergudangan setiap nilai sel menunjukkan potensi suatu perkembangan untuk tiap jenis penggunaan lahan industri dan pergudangan, dimana semakin besar nilai sel (warna merah) maka pada lokasi tersebut akan berpotensi terjadi perubahan menjadi industri dan pergudangan, sebaliknya jika memiliki nilai sel (warna hijau) yang semakin rendah lokasi tersebut tidak berpotensi untuk terjadi perubahan. Begitu juga untuk penggunaan lahan pergudangan dan jasa serta permukiman. Adapun peta potensi perkembangan penggunaan lahan (a) industri dan pergudangan, (b) perdagangan dan jasa serta (c) permukiman dapat dilihat pada Gambar 4. 
Ukuran dan bentuk neighbourhood yang digunakan pada studi ini adalah $3 \times 3$ (Pratomoatmojo, 2018). Operasi yang digunakan neighborhood filter, dalam penelitian ini yaitu operasi penjumlahan (sum) dimana hasil perkalian antara nilai sel dengan grid kemudian akan dijumlahkan untuk mendapatkan nilai sel inti. Neighbourhoud filter berfungsi menentukan rasio pengaruh bobot antara sel inti dan sel di sekitarnya. Dalam penentuan constraint variable didasarkan pada pengamatan dari hasil pola perubahan penggunaan lahan yang terjadi. Pada prinsipnya wilayah yang ditetapkan sebagai constraint variable tidak dapat dikembangkan untuk suatu jenis penggunaan lahan sehingga perkembangannya akan mencari lokasi yang lain yang sesuai. Pada penelitian ini untuk sungai dan taman kota ditetapkan sebagai penggunaan lahan yang tidak dapat berubah, selain itu pertanian dan permukiman tidak dapat merubah pengunan lahan industri dan pergudangan serta perdagangan dan jasa.

\section{Uji Validitas Model}

Uji akurasi model diperlukan untuk mengukur tingkat akurasi model prediksi sehingga dapat diketahui tingkat validitasnya. Pada studi ini nilai akurasi (dalam persen) dihitung dari luas cell pengunaan lahan hasil simulasi tahun 2017 dengan luas eksisting tahun 2017. Peta penggunaan lahan hasil simulasi tahun 2017 dengan peta penggunaan lahan eksisting tahun 2017 dilakukan operasi overlay untuk mengetahui nilai akurasi dari model yang dibangun. Hasil analisis menunjukkan nilai overall accuracy dari model yang dibangun sebesar $84,18 \%$, dimana dalam sebuah pemodelan tingkat nilai akurasi diatas $70,00 \%$ dapat dikatakan bagus (Pratomoatmojo, 2018). Dengan hasil akurasi tersebut kemudian model dapat dilakukan untuk analisis selanjutnya yaitu prediksi penggunaan lahan tahun 2031.

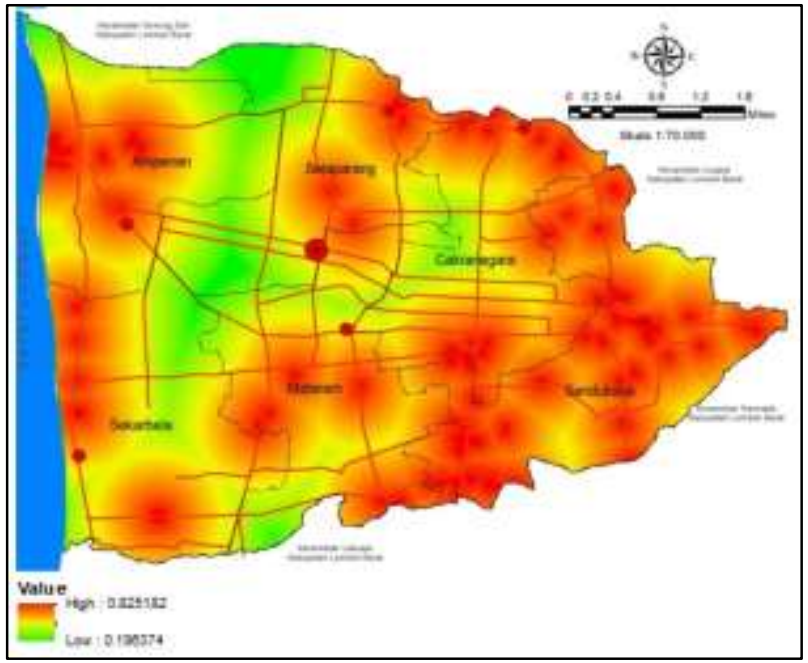

Gambar 4a. Peta Potensi Perkembangan Penggunaan Lahan Industri dan Pergudangan

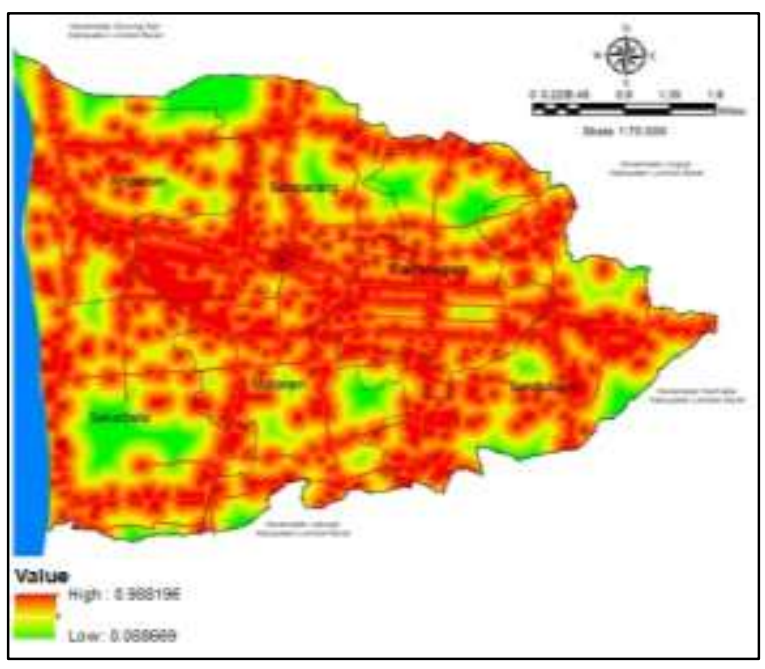

Gambar 4b. Peta Potensi Perkembangan Penggunaan Lahan Perdagangan dan Jasa

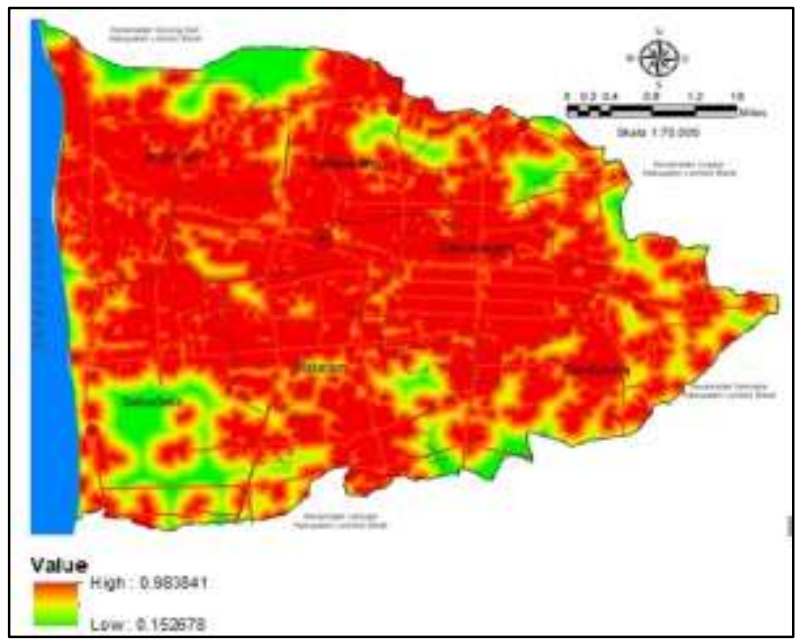

Gambar 4c. Peta Potensi Perkembangan Penggunaan Lahan Permukiman 
Tabel 2. Ketelitian Model Penggunaan Lahan

\begin{tabular}{|c|c|c|c|c|c|c|c|c|c|c|}
\hline \multirow{2}{*}{\multicolumn{2}{|c|}{$\begin{array}{c}\text { Penggunaan } \\
\text { Lahan Kota } \\
\text { Mataram }\end{array}$}} & \multicolumn{7}{|c|}{ Luas Simulasi Penggunaan Lahan Tahun 2017 (cell) } & \multirow[b]{2}{*}{ Total } & \multirow[b]{2}{*}{$\begin{array}{l}\text { Ketelitian } \\
(\%)\end{array}$} \\
\hline & & LU_1 & LU_2 & LU_3 & LU_4 & LU_5 & LU_6 & LU_7 & & \\
\hline \multirow{7}{*}{ 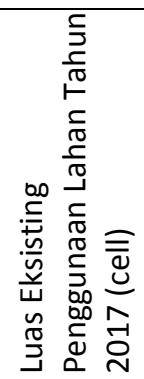 } & LU_1 & 5.512 & 518 & & 719 & 887 & & & 7.636 & 72,18 \\
\hline & LU_2 & 348 & 58.003 & & 8.462 & 8.629 & & 3 & 75.445 & 76,88 \\
\hline & LU_3 & & & 7.177 & & & & & 71.77 & 100,00 \\
\hline & LU_4 & 356 & 16.225 & 1 & 254.594 & 35.097 & & 2 & 306.275 & 83,13 \\
\hline & LU_5 & 969 & 455 & & 22.590 & 178.112 & & & 202.126 & 88,12 \\
\hline & LU_6 & & & & & 1 & 1.792 & & 1.793 & 100,00 \\
\hline & LU_7 & & & & 1 & 5 & & 1.671 & 1.677 & 99,64 \\
\hline \multicolumn{2}{|c|}{ Total } & 7.185 & 75.201 & 7.178 & 286.366 & 222.731 & 1.792 & 1.676 & 602.130 & 84,18 \\
\hline
\end{tabular}

Keterangan LU_1 : Industri dan Pergudangan, LU_2 : Perdagangan dan Jasa, LU_3 : Transportasi, LU_4 : Permukiman, LU_5 : Pertanian, LU_6: Sungai dan LU_7 : Taman Kota.

Uji akurasi model telah dilakukan pada beberapa penelitian terkait, seperti penelitian Gharbia, dkk. (2016) yang membangun model untuk prediksi penggunaan lahan terkait perluasan kota pada tahun 2020, tahun 2050 dan tahun 2080 di daerah cekungan Shannon di Irlandia dengan akurasi model yang diperoleh pada tahun 2006 adalah sebesar 89,01\% dan untuk tahun 2012 adalah sebesar $87,09 \%$. Kemudian Sadewo dan Buchori (2018) membangun model perubahan penggunaan lahan dengan memprediksi perubahan penggunaan lahan akibat pengaruh pembangunan kawasan industri di Kendal, hasil akurasi model yang diperoleh $95,68 \%$. Adanya perbedaan tingkat akurasi dalam setiap penelitian tersebut bisa disebabkan karena identifikasi penggunaan lahan yang belum sesuai kondisi eksisting, penentuan faktor-faktor pendorong perubahan penggunaan lahan dan pembobotan yang kurang tepat. Tabel 2 menunjukkan ketelitian model penggunaan lahan.

\section{Peta Prediksi Penggunaan Lahan}

Peta prediksi penggunaan lahan tahun 2031 dibangun menggunakan peta dasar penggunaan lahan tahun 2017 sebagai input data multitemporal. Jumlah sel lahan yang berubah hasil prediksi, peta transisi penggunaan lahan yang merupakan peta probabilitas perubahan penggunaan lahan dari hasil analisis jangkauan dan bobot faktor pendorong perubahan penggunaan lahannya, neighborhood filter dan land constraint penggunaan lahan. Dari tahun 2017 hingga 2031 terjadi perubahan penggunaan lahan dengan persentase paling besar adalah perdagangan dan jasa sebesar 47,08\%, kemudian permukiman sebesar $15,76 \%$, industri dan pergudangan sebesar $12.88 \%$. Sementara untuk lahan pertanian mengalami penurunan sebesar 41,96\%. Pada tahun 2031 luas penggunaan lahan untuk industri dan pergudangan, perdagangan dan jasa, sarana transportasi, permukiman, pertanian, sungai dan taman kota adalah masing-masing sebesar 86,414 ha, 1.110 , 139 ha, $72,028,3.544,846$ ha, $1.173,062$ ha, 17,930 ha dan 16,625 ha.

Dari hasil penelitian ini dilakukan perbandingan antara prediksi perubahan lahan tahun 2031 dengan peta rencana pola ruang RTRW (Gambar 5). Peta rencana pola ruang yang bersumber dari Bappeda Kota Mataram tersebut terlebih dahulu diklasifikasi kembali dengan menyesuaikan klasifikasi penggunaan lahan pada penelitian ini. Pada perbandingan luasan penggunaan lahan antara prediksi tahun 2031 dengan luasan berdasar pola ruang RTRW didapatkan luasan yang cukup berbeda antara jenis penggunaan lahan yang sama. Hal ini kemungkinan disebabkan pada saat penyusunan pola ruang RTRW belum mempertimbangkan kebutuhan penggunaan lahan sesuai dengan trend pada saat itu dengan mempertimbangkan faktor pendorong maupun penghambat laju perubahan penggunaan lahan. Pada penggunaan lahan berdasar pola ruang RTRW untuk industri dan pergudangan sebesar 21,003 hektar, sedangkan pada hasil prediksi diperoleh sebesar 86,414 hektar terdapat selisih sebesar 65,411 hektar atau sebesar $311,43 \%$. 


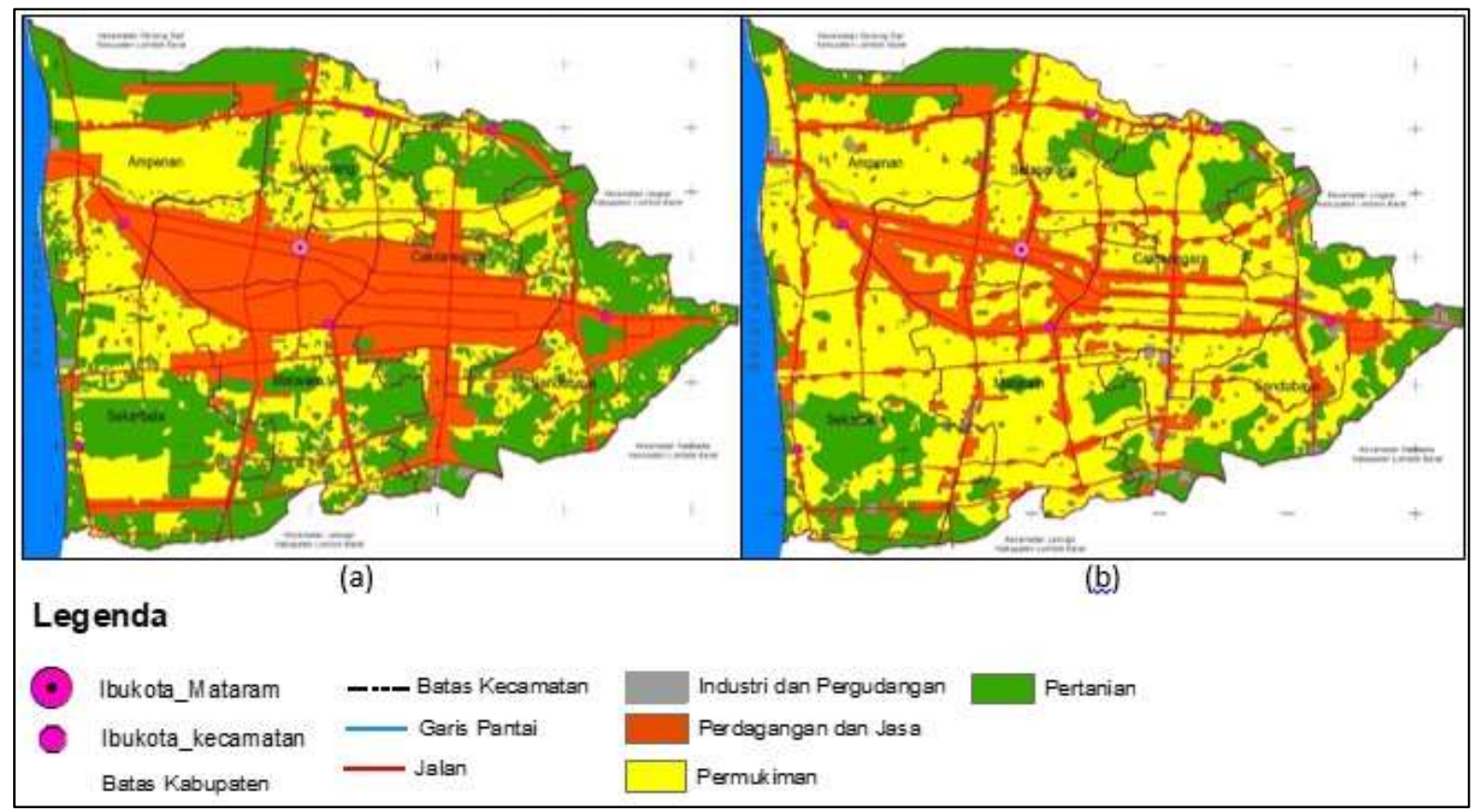

Gambar 5. Perbandingan Peta (a) Pola Ruang RTRW dengan (b) Prediksi Tahun 2031

Untuk luasan perdagangan dan jasa pada pola ruang RTRW sebesar 1.758,201 hektar sedangkan pada prediksi penggunaan lahan sebesar 1.197,362 hektar terdapat selisih sebesar 560,839 hektar atau sebesar 31,89\%. Untuk luasan permukiman pada pola ruang RTRW sebesar 2.155,147 hektar sedangkan pada prediksi penggunaan lahan sebesar $3.562,776$ hektar terdapat selisih sebesar 1.407,629 hektar atau sebesar $65,31 \%$.

\section{KESIMPULAN}

Pola perubahan penggunaan lahan di Kota Mataram dari tahun 2008 sampai dengan 2017, menunjukkan peningkatan luasan penggunaan lahan industri dan pergudangan menjadi 76,553 hektar, penggunaan lahan perdagangan dan jasa menjadi 754,795 hektar serta penggunaan lahan permukiman menjadi 3.062,149 hektar. Akan tetapi pada penggunaan lahan pertanian berkurang menjadi 2.020,969 hektar.

Penentuan faktor-faktor pendorong perubahan dan bobot masing-masing faktor serta aturan transisi merupakan hal yang penting untuk membangun model prediksi perubahan lahan. Hasil pehitungan validitas menujukkan tingkat akurasi model sebesar 84,18\%. Pada tahun 2031 kebutuhan penggunaan lahan untuk industri sebesar 86,414 hektar, perdagangan dan jasa sebesar 1.108,709 hektar, sarana transportasi sebesar 72,028 hektar, permukiman sebesar 3.544,846 hektar, sungai sebesar 17,930 hektar dan taman kota sebesar 16,625 hektar, sedangkan untuk pertanian kebutuhan penggunaan lahannya berkurang menjadi sebesar 1.170,062 hektar.

Berdasarkan hasil prediksi penggunaan lahan tahun 2031 terlihat ketidaksesuaian antara pola penggunaan lahan seperti kawasan industri dan pergudangan, perdagangan dan jasa serta permukiman dengan pola ruang RTRW sehingga perlu penataan kembali rencana tata ruang wilayah Kota Mataram yang mengacu kepada kebutuhan lahan dengan memperhitungkan faktor pendorong maupun penghambat. Pemanfaatan simulasi perubahan penggunaan lahan dengan konsep cellular automata ini dapat diterapkan untuk membantu mengkaji ulang Rencana Tata Ruang Wilayah (RTRW), penyusunan Rencana Detail Tata Ruang (RDTR) serta perencanaan dan pengendalian pembangunan, sehingga perencanaan penataan ruang di Kota Mataram dapat berjalan sesuai dengan kebutuhan dan sesuai dengan prinsip pembangunan berkelanjutan. 


\section{DAFTAR PUSTAKA}

Aryany, P. A., \& Pradoto, W. (2014). Perubahan Penggunaan Lahan di Kawasan Sekitar Bukit Semarang Baru. Teknik PWK (Perencanaan Wilayah Kota), 3(1), 96-105. Retrieved from

https://ejournal3.undip.ac.id/index.php/p wk/article/view/4385

Barredo, J. I., Kasanko, M., McCormick, N., \& Lavalle, C. (2003). Modelling Dynamic Spatial Processes: Simulation of Urban Future Scenarios Through Cellular Automata. Landscape and Urban Planning, 64(3), 145-160. doi:10.1016/S01692046(02)00218-9

Cohen, B. (2006). Urbanization in Developing Countries: Current Trends, Future Projections, and Key Challenges for Sustainability. Technology in Society, 28(1), 63-80. doi:10.1016/j.techsoc.2005.10.005

Dadras, M., Shafri, H. Z. M., Ahmad, N., Pradhan, B., \& Safarpour, S. (2015). Spatio-temporal Analysis of Urban Growth from Remote Sensing Data in Bandar Abbas City, Iran. The Egyptian Journal of Remote Sensing and Space Science, 18(1), 35-52. doi:10.1016/j.ejrs.2015.03.005

Deep, S., \& Saklani, A. (2014). Urban Sprawl Modeling Using Cellular Automata. The Egyptian Journal of Remote Sensing and Space Science, 17(2), 179-187. doi:10.1016/j.ejrs.2014.07.001

Dendoncker, N., Rounsevell, M., \& Bogaert, P. (2007). Spatial Analysis and Modelling of Land Use Distributions in Belgium. Computers, Environment and Urban Systems, 31(2), 188-205. doi:10.1016/j.compenvurbsys.2006.06.004

Fuglsang, M., Münier, B., \& Hansen, H. S. (2013). Modelling Land-use Effects of Future Urbanization Using Cellular Automata: an Eastern Danish case. Environmental Modelling \& Software, 50, 1-11. doi:10.1016/j.envsoft.2013.08.003

Gharbia, S. S., Alfatah, S. A., Gill, L., Johnston, P., \& Pilla, F. (2016). Land Use Scenarios and Projections Simulation Using an Integrated GIS Cellular Automata Algorithms.
Modeling Earth Systems and Environment, 2(3), 151. doi:10.1007/s40808-016-0210-y

Gu, W., Guo, J., Fan, K., \& Chan, E. H. W. (2016). Dynamic Land Use Change and Sustainable Urban Development in a Third-tier City within Yangtze Delta. Procedia Environmental Sciences, 36, 98-105. doi:10.1016/j.proenv.2016.09.019

Kaiser, E. J., Godschalk, D. R., \& Chapin, F. S. (1995). Urban Land Use Planning (Vol. 4). Chicago: University of Illinois Press Urbana.

Liu, Y., \& He, J. (2009). Developing a Web-based Cellular Automata Model for Urban Growth Simulation. Artikel dipresentasikan di International Symposium on Spatial Analysis, Spatial-temporal Data Modeling, and Data Mining, Wuhan, China.

Longley, P., \& Batty, M. (2003). Advanced Spatial Analysis: the CASA Book of GIS. London: ESRI, Inc.

Mosammam, H. M., Nia, J. T., Khani, H., Teymouri, A., \& Kazemi, M. (2017). Monitoring Land Use Change and Measuring Urban Sprawl Based on its Spatial Forms: the case of Qom City. The Egyptian Journal of Remote Sensing and Space Science, 20(1), 103-116. doi:10.1016/j.ejrs.2016.08.002

Pratomoatmojo, N. A. (2018). LanduseSim Methods: Land Use Class Hierarchy for Simulations of Multiple Land Use Growth. IOP Conference Series: Earth and Environmental Science, 202, 012023. doi:10.1088/1755-1315/202/1/012023

Sadewo, M. N., \& Buchori, I. (2018). Simulasi Perubahan Penggunaan Lahan Akibat Pembangunan Kawasan Industri Kendal (KIK) Berbasis Cellular Automata. 2018, 32(2), 13. doi:10.22146/mgi.32272

United Nations. (2018). 2018 Revision of World Urbanization Prospects. Diakses dari https://www.un.org/development/desa/p ublications/2018-revision-of-worldurbanization-prospects.html, 28 Juni 2018

White, R., Engelen, G., \& Uljee, I. (1997). The Use of Constrained Cellular Automata for HighResolution Modelling of Urban Land-Use Dynamics. Environment and Planning B: Planning and Design, 24(3), 323-343. doi:10.1068/b240323

Wolfram, S. (1982). Cellular Automata as Simple Self-Organizing Systems. Caltech preprint. 
Diakses

dari

https://www.stephenwolfram.com/publica tions/academic/cellular-automata-self-

organizing-systems.pdf., 20 Juli 2018 